\title{
Overexpression of the fibroblast growth factor receptor-1 gene correlates with liver metastasis in colorectal cancer
}

\author{
TSUTOMU SATO $^{1}$, TAKASHI OSHIMA ${ }^{1}$, KAZUE YOSHIHARA ${ }^{1}$, NAOTO YAMAMOTO ${ }^{1}$, ROPPEI YAMADA ${ }^{1}$, \\ YASUHIKO NAGANO ${ }^{1}$, SHOICHI FUJII ${ }^{1}$, CHIKARA KUNISAKI ${ }^{1}$, MANABU SHIOZAWA ${ }^{2}$, MAKOTO AKAIKE ${ }^{2}$, \\ YASUSHI RINO $^{3}$, KATSUAKI TANAKA ${ }^{1}$, MUNETAKA MASUDA ${ }^{3}$ and TOSHIO IMADA ${ }^{4}$ \\ ${ }^{1}$ Gastroenterological Center, Yokohama City University Medical Center, 4-57 Urafune-cho, Minami-ku, \\ Yokohama-shi, Kanagawa-ken 232-0024; ${ }^{2}$ Department of Surgery, Kanagawa Cancer Center, 1-1-2 Nakao, \\ Asahi-ku, Yokohama-shi, Kanagawa-ken 241-0815; ${ }^{3}$ Department of Surgery, ${ }^{4}$ Yokohama City University, \\ 3-9 Fukuura, Kanazawa-ku, Yokohama-shi, Kanagawa-ken 236-0004, Japan
}

Received July 18, 2008; Accepted October 15, 2008

DOI: $10.3892 /$ or_00000210

\begin{abstract}
Expression of the fibroblast growth factor (FGF)-1, $F G F-2$, fibroblast growth factor receptor (FGFR)-1, and $F G F R-2$ genes has been reported in various cancers and is associated with poor outcomes in patients with solid tumors. This study examined the relations between the relative expression of the FGF genes and clinicopathological factors, especially invasion and metastasis, in patients with colorectal cancer. We studied surgical specimens of cancer tissue and adjacent normal mucosa obtained from 202 patients with untreated colorectal carcinoma. The relative expression levels of $F G F-1, F G F-2, F G F R-1$, and FGFR-2 mRNA in cancer and in normal adjacent mucosa were measured by quantitative real-time, reverse-transcription polymerase chain reaction. The relative expression level of the FGFR-2 gene was higher in normal adjacent mucosa than in cancer, whereas the relative expression levels of the $F G F-1, F G F-2$, and FGFR-1 genes were similar. FGFR-1 gene expression levels were higher in the presence than in the absence of liver metastasis. An analysis of the relation between clinicopathological features and gene expression showed that overexpression of FGFR-1 correlated with liver metastasis. Our results suggested that overexpression of the FGFR-1 gene might lead to liver metastasis in colorectal cancer. Overexpression of the FGFR-1 gene may thus be a useful predictor of liver metastasis in patients with colorectal cancer.
\end{abstract}

Correspondence to: Dr Tsutomu Sato, Gastroenterological Center, Yokohama City University Medical Center, 4-57 Urafune-cho, Minami-ku, Yokohama-shi, Kanagawa-ken 232-0024, Japan E-mail: t-sato@urahp.yokohama-cu.ac.jp

Key words: fibroblast growth factor-1, -2, fibroblast growth factor receptor-1, -2 , colorectal cancer

\section{Introduction}

Fibroblast growth factors (FGFs) are a family of heparinbinding growth factors. FGFs promote angiogenesis by interacting with various endothelial cell-surface receptors, including tyrosine kinase receptors, heparin-sulfate proteoglycans, and integrins. The relation between angiogenesis and tumor growth is well established, and numerous inducers of angiogenesis have been identified (1). Gospodarowicz (2) discovered FGF-2 in 1974. This protein was found to strongly promote the proliferation of fibroblasts. Since then, 22 structurally-related members of the FGF family and 4 FGFhomologous factors have been identified. FGFs exert their biological activities by binding to high-affinity tyrosine kinase FGF receptors (FGFRs) on the surface of target cells. Angiogenic potential has been assessed for only a limited number of the 22 members of the FGF family in vitro and in vivo. Most experimental studies have focused on the prototypes FGF-1 and FGF-2 (3).

FGFs exert their biologic activity by interacting with highaffinity FGFRs. Four members of the FGFR family (FGFR-1, FGFR-2, FGFR-3, and FGFR-4) are encoded by distinct genes, and their structural variability is increased by alternative splicing. FGFR-1 is expressed by endothelial cells in vivo and in vitro. Some cultured endothelial cells can express FGFR-2 $(3,4)$.

Expression levels of the $F G F-1, F G F-2, F G F R-1$, and $F G F R-2$ genes have been examined in various cancers, including breast cancer (5-8), brain tumors (9-12), hepatocellular carcinoma (13-15), cervical and esophageal cancers (16-20), and pancreatic cancer (21-23). Correlations between $F G F-1$ and $F G F R-1$ expression in breast cancer (5) and esophageal cancer (17) and between FGF-2 and FGFR-1 in hepatocellular carcinoma (13) have suggested that these factors promote proliferation of cancer cells in an autocrine manner.

Numerous studies have demonstrated that FGFR-1 correlates with angiogenesis and carcinogenesis. Acevedo et al (24) reported that FGFR-1 promotes the progression of prostate cancer in a mouse model. Freier et al (19) found that increased 
Table I. PCR primers and conditions.

\begin{tabular}{|c|c|c|c|}
\hline Gene & Primer & $\begin{array}{l}\text { Annealing } \\
\text { temperature }(\mathrm{C})\end{array}$ & Product size (bp) \\
\hline$F G F-1$ & $\begin{array}{l}\text { 5'-CATTACCACGCCTTGACC-3' } \\
\text { 5'-AGCCAGTTTCCCTTTCTTTC-3' }\end{array}$ & 58.0 & 175 \\
\hline$F G F-2$ & $\begin{array}{l}\text { 5'-AGCGACCCTCACATCAAG-3' } \\
\text { 5'-ATCTTCCATCTTCCTTCATAGC-3' }\end{array}$ & 58.0 & 106 \\
\hline$F G F R-1$ & $\begin{array}{l}\text { 5'-GGCTGTATGAAAAGGGTGGGAATG-3' } \\
\text { 5'-GGTGCGTCGTGAGGTCTGG-3' }\end{array}$ & 62.0 & 152 \\
\hline$F G F R-2$ & $\begin{array}{l}\text { 5'-ATCTGCCTGGTCGTGGTC-3' } \\
\text { 5'-GCTCTAATGTGGTATCCTCAAC-3' }\end{array}$ & 60.0 & 82 \\
\hline$\beta$-actin & $\begin{array}{l}\text { 5'-AGTTGCGTTACACCCTTTCTTGAC-3' } \\
\text { 5'-GCTCGCTCCAACCGACTGC-3' }\end{array}$ & 60.0 & 171 \\
\hline
\end{tabular}

FGFR-1 expression contributes to carcinogenesis during the early development of oral squamous cell carcinoma. Freeman et al (25) showed that activation of FGFR-1, but not FGFR-2, led to strong up-regulation of osteopontin, associated with prostate cancer progression and metastasis. Feng et al (26) reported that FGFR-2 limits and FGFR-1 accelerates the tumorigenicity of prostate epithelial cells.

Expression of FGFs and FGFRs in colorectal cancer has been reported by various studies. Jang et al showed that FGFR-1 is overexpressed in colorectal carcinoma cells and associated with tumorigenesis $(27)$. Galzie et al $(28,29)$ demonstrated a relation between FGF-2 production and the invasive potential of human colorectal carcinoma cells. To date, however, few studies have examined the relations between expression levels of FGFs and FGFRs and clinicopathological features in colorectal cancer.

We measured expression levels of the $F G F-1, F G F-2$, $F G F R-1$, and FGFR-2 genes in 202 paired specimens of cancer tissue and adjacent normal mucosa obtained from patients with colorectal cancer. To evaluate the clinical significance of these FGFs, we examined correlations between the relative expression of these genes and clinicopathological features.

\section{Materials and methods}

Patients and samples. We studied surgical specimens of cancer tissue and adjacent normal mucosa obtained from 202 patients with untreated colorectal carcinoma. The patients underwent surgery at the Gastroenterological Center, Yokohama City Medical Center, and at Kanagawa Cancer Center between 2002 and 2006. Informed consent was obtained from each patient, and the Ethics Committees of Yokohama City Medical Center and Kanagawa Cancer Center approved the protocol before initiation of the study. Each tissue sample was embedded in O.C.T. compound (Sakura Finetechnical Co., Ltd., Tokyo) and immediately stored at $-80^{\circ} \mathrm{C}$ until use. No patient had any other malignancies. Tissue specimens were stained with hematoxylin and eosin and examined histopathologically. Sections that consisted of $>80 \%$ carcinoma cells were used to prepare total RNA.
A

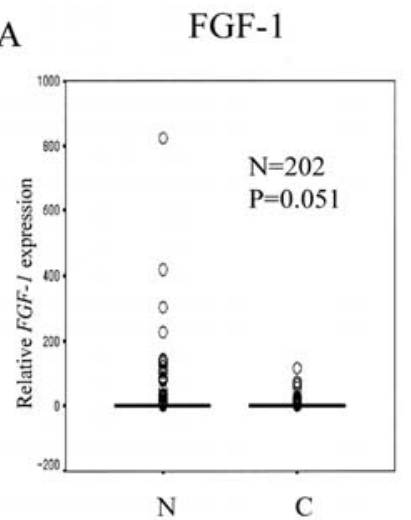

B

FGF-2

C

FGFR-1

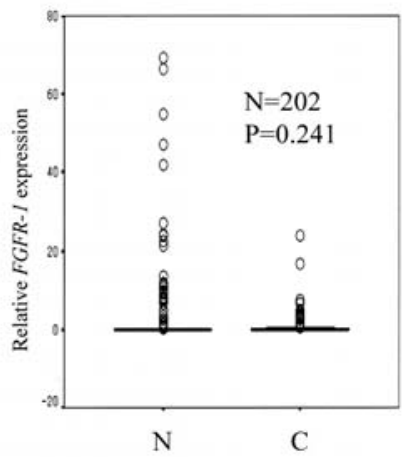

D

FGFR-2

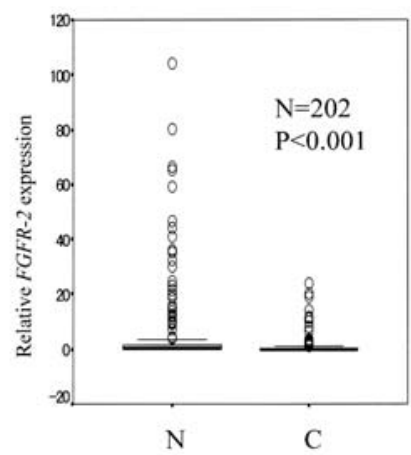

Figure 1. Comparison of $F G F-1, F G F-2, F G F R-1$, and FGFR-2 mRNA expression between colorectal cancer tissue $(C)$ and adjacent normal mucosa (N). FGFR-2 gene expression levels were higher in normal adjacent mucosa than in cancer tissue $(\mathrm{P}<0.001) . F G F-1, F G F-2$, and $F G F R-1$ gene expression levels were similar in normal tissue and cancer tissue $(\mathrm{P}=0.051, \mathrm{P}=0.920$, $\mathrm{P}=0.241)$.

Quantitative real-time, reverse-transcription polymerase chain reaction (PCR). Total RNA isolated from colorectal cancer tissue and adjacent normal mucosa was prepared with the use of Trizol (Gibco, Life Tech, Gaithersburg, MD). Complemetary DNA (cDNA) was synthesized from $2 \mu \mathrm{g}$ of total RNA with an iScript cDNA synthesis kit (Bio-Rad Laboratories, Hercules, CA). After synthesis, the cDNA was 
A

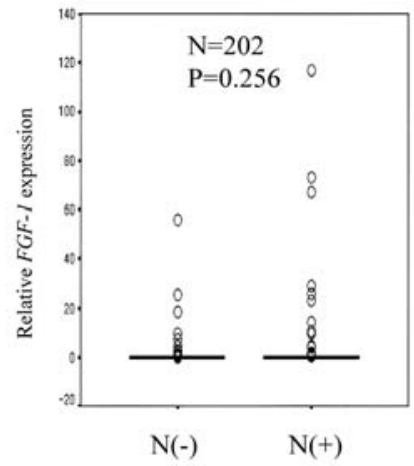

$\mathrm{C}$

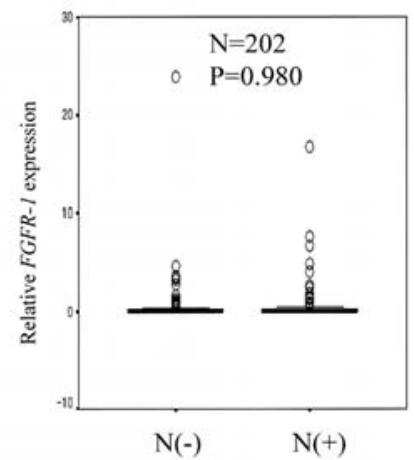

B

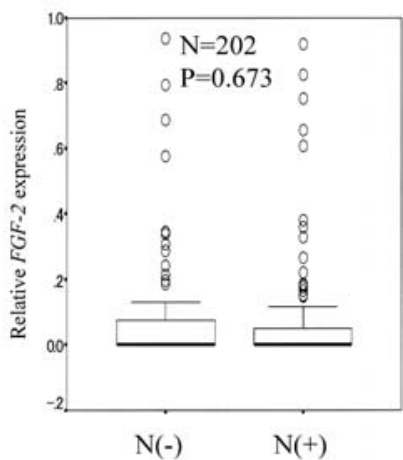

$\mathrm{D}$

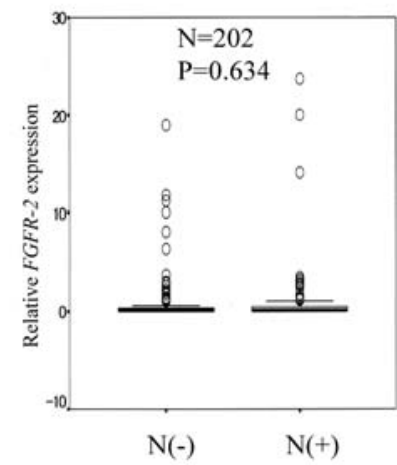

Figure 2. Associations of FGF-1, FGF-2, FGFR-1, and FGFR-2 gene expression with lymph node metastasis in 202 patients with colorectal cancer. There was no significant association between the expression level of any gene and the presence or absence of lymph node metastasis. P-values were calculated by the Mann-Whitney U test.

diluted 1:4 with water and stored at $-20^{\circ} \mathrm{C}$ until use. Quantitative real-time PCR was performed with an iQ SYBR-Green Supermix (Bio-Rad Laboratories). PCR reactions were carried out in a total volume of $15 \mu 1$, containing cDNA derived from $75 \mathrm{ng}$ of RNA, $0.27 \mu \mathrm{M}$ of each primer, $7.5 \mu \mathrm{l}$ of iQ SYBRGreen Supermix containing dATP, dCTP, dGTP, and dTTP at concentrations of $400 \mu \mathrm{M}$ each, and $50 \mathrm{U} / \mathrm{ml}$ of iTag DNA polymerase. The PCR consisted of $10 \mathrm{~min}$ at $94^{\circ} \mathrm{C}$, followed by 50 cycles of denaturation of the cDNA for $30 \mathrm{sec}$ at $94^{\circ} \mathrm{C}$, annealing for $30 \mathrm{sec}$ at an appropriate temperature (Table I), and a primer extension for $1 \mathrm{~min}$ at $72^{\circ} \mathrm{C}$ followed by $72^{\circ} \mathrm{C}$ for $10 \mathrm{~min}$. The PCR primer sequences of $F G F-1, F G F-2$, FGFR-1, FGFR-2, and B-actin, used as an internal control, are shown in Table I.

Statistical analysis. Gene expression levels of colorectal cancer were compared with those of normal adjacent mucosa with the use of the Wilcoxon test. Relations between gene expression and potential explanatory variables, including age, gender, tumor size, histological type, depth of invasion, lymph node metastasis, location, lymphatic invasion, venous invasion, and liver metastasis, were evaluated with the $\chi^{2}$ test.

Associations between variables were assessed using the Mann-Whitney U test. Correlation coefficients between the different variables were calculated by simple regression analysis. Each statistical analysis was performed using the Dr SPSS II program, version 11.0.1J for Windows (SPSS Inc.,

A

FGF-1

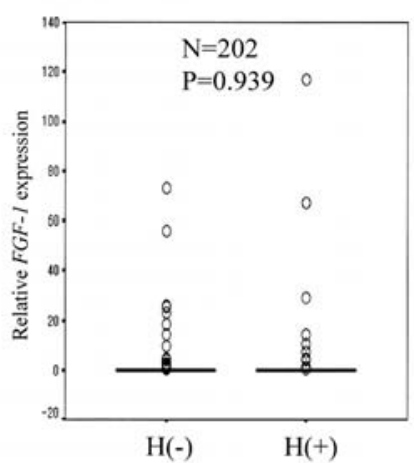

C

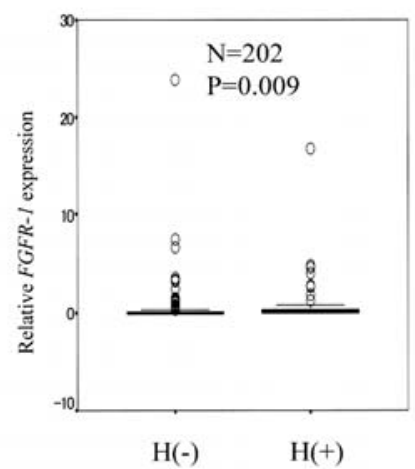

B

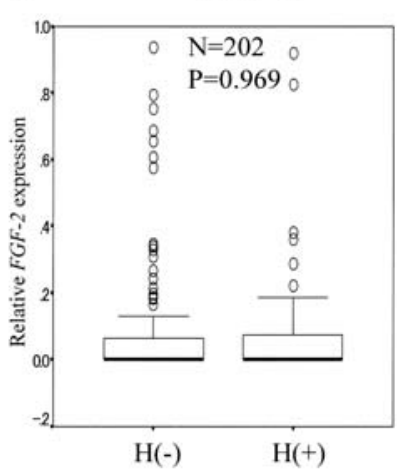

D

FGFR-2

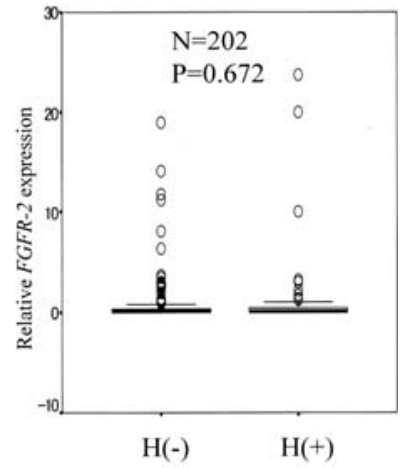

Figure 3. Associations of FGF-1, FGF-2, FGFR-1, and FGFR-2 gene expression with liver metastasis in patients with colorectal cancer. There was no significant association between the expression levels of the $F G F-1$, $F G F-2$, and $F G F R-2$ genes and the presence or absence of liver metastasis $(\mathrm{P}=0.939, \mathrm{P}=0.969, \mathrm{P}=0.672)(\mathrm{A}, \mathrm{B}$ and $\mathrm{D}) . F G F R-1$ gene expression levels were higher in the presence than in the absence of liver metastasis $(\mathrm{P}=0.009)$ (C). P-values were calculated by the Mann-Whitney U test.

Chicago, IL, USA). Two-sided P-values were calculated, and a difference was considered statistically significant at $\mathrm{P}<0.05$.

\section{Results}

Comparison of FGF-1, FGF-2, FGFR-1, and FGFR-2 mRNA expression between colorectal cancer tissue and adjacent normal mucosa. FGFR-2 gene expression levels were higher in normal adjacent mucosa than in cancer tissue $(\mathrm{P}<0.001)$ (Fig. 1D). FGF-1, FGF-2, and FGFR-1 gene expression levels were similar in normal tissue and cancer tissue $(\mathrm{P}=0.051$, $\mathrm{P}=0.920, \mathrm{P}=0.241$ ) (Fig. 1A-C).

Associations of FGF-1, FGF-2, FGFR-1, and FGFR-2 gene expression with lymph node metastasis in patients with colorectal cancer. There was no significant association between the expression level of any gene and the presence or absence of lymph node metastasis (Fig. 2).

Associations of FGF-1, FGF-2, FGFR-1, and FGFR-2 gene expression with liver metastasis in patients with colorectal cancer. There was no significant association between the expression levels of the FGF-1, FGF-2, and FGFR-2 genes and the presence or absence of liver metastasis $(\mathrm{P}=0.939$, $\mathrm{P}=0.969, \mathrm{P}=0.672$ ) (Fig. 3A, B and D). FGFR-1 gene 


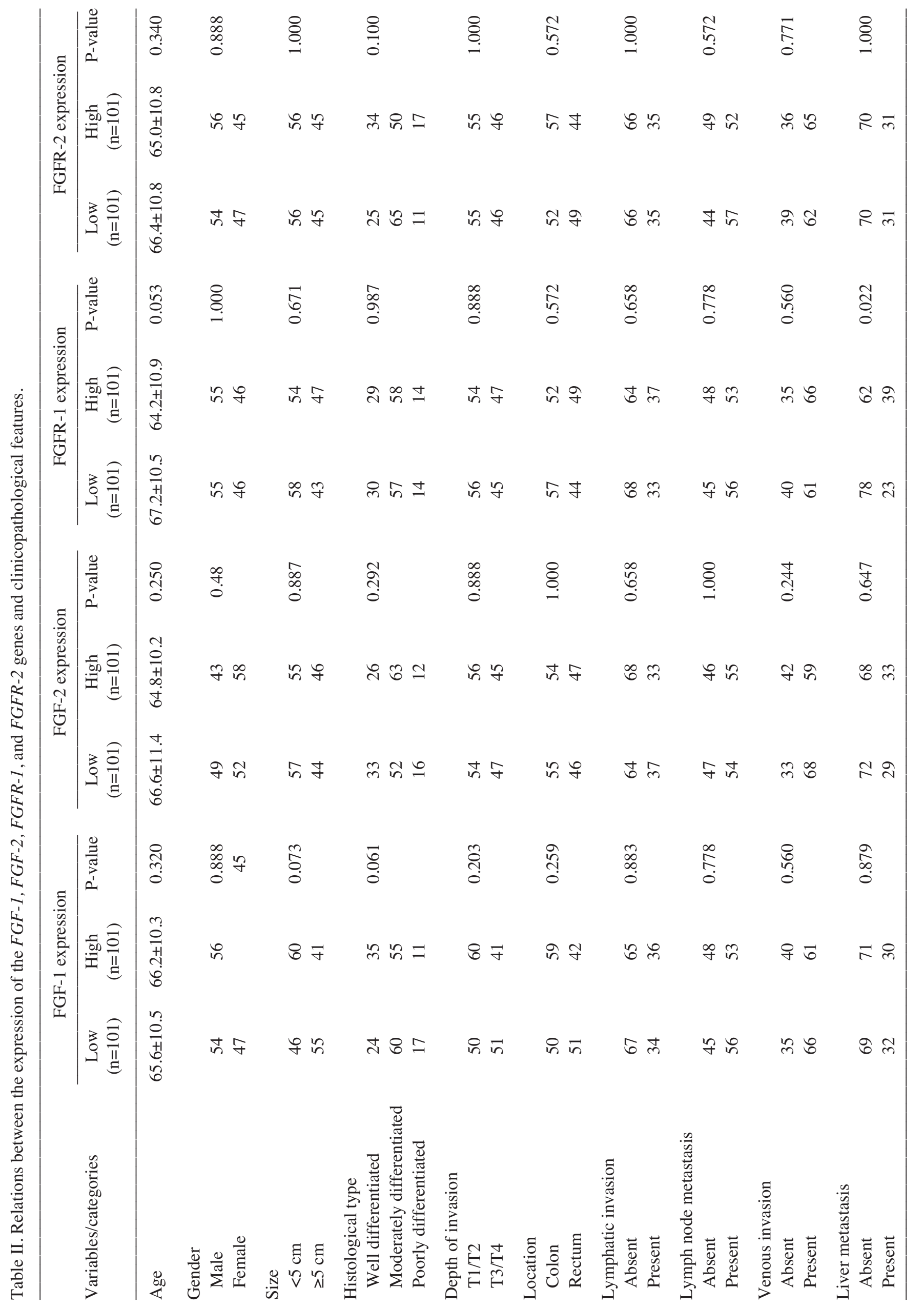


expression levels were higher in the presence than in the absence of liver metastasis $(\mathrm{P}=0.009)$ (Fig. 3C)

Relations of FGF-1, FGF-2, FGFR-1, and FGFR-2 gene expression levels to clinicopathological features. Expression levels of the FGF-1, FGF-2, FGFR-1, and FGFR-2 genes were categorized as low or high according to their median values. The relation between the expression of these genes and clinicopathological features was then examined. The expression levels of the $F G F-1, F G F-2$ and FGFR-2 genes were unrelated to age, gender, tumor size, lymph node metastasis, and lymphatic invasion. FGFR- 1 expression correlated with liver metastasis $(\mathrm{P}=0.022)$ (Table II).

\section{Discussion}

Cancer-cell invasion is associated with tumor stromal fibrosis. Cancer cells interact with surrounding fibroblasts proliferating at the invasion front by producing various factors, thereby promoting cancer-cell proliferation and invasion $(1,3)$. Previous studies have shown that FGFs and FGFRs are overexpressed in cancer cells and fibroblasts (30). We therefore studied expression levels of the $F G F-1, F G F-2, F G F R-1$, and FGFR-2 genes in colorectal cancer tissue and adjacent normal mucosa.

We first compared the mRNA expression levels of each of these genes between colorectal cancer tissue and adjacent normal mucosa. Bansal et al (7) reported that the expression of FGF-1 is lower in breast cancer than in the normal human breast. Myoken et al (31) showed stronger expression of FGF-2 in oral squamous cell carcinomas than in normal tissue. Chow et al (14) demonstrated strong expression of FGF-1 and FGF-2 in normal liver cells, but weak expression of these factors in cancer cells. Yoshimura et al (5) and Jang et al (27) reported increased expression of FGFR-1 in cancer cells. Sahadevan et al (32) showed significant overexpression of FGFR-1 protein, but not of FGFR-2 protein, in prostate cancer. In our study, the expression level of the FGFR-2 gene was higher in normal adjacent mucosa, whereas the expression levels of the $F G F-1, F G F-2$, and $F G F R-1$ genes did not differ significantly between cancer tissue and normal adjacent mucosa.

Second, we examined whether the expression levels of the FGF-1, FGF-2, FGFR-1, and FGFR-2 genes in cancer tissue were related to clinicopathological factors such as lymph node metastasis and liver metastasis. Sugiura et al (17) reported that FGFR-1 expression was not associated with lymph node metastasis. In contrast, Takanami et al (33) and Hase et al (16) reported that FGFR-1 expression was related to lymph node metastasis. As for liver metastasis, only a few studies have commented on the relation to FGFR-1 expression. Suyama et al (34) suggested that synergy between N-cadherin and FGFR-1 alters the duration of Mitogen-activated protein kinase(MAPK)-extracellular signal-regulated kinase (ERK) signals, leading to distant metastasis. In our study, the expression level of the FGFR-1 gene was unrelated to lymph node metastasis, but was significantly higher in the presence than in the absence of liver metastasis.

We then examined the relation between FGF gene expression levels and clinicopathological features. Among the many studies addressing this topic (1), Sahadevan et al (32) found no association of FGFR-1 or FGFR-2 expression levels with clinical stage or distant metastasis in prostate cancer. Han et al (35) showed significant correlations of FGF-2 expression with the depth of invasion, clinical stage, and lymph node metastasis in oral squamous cell carcinoma. Mano et al (36) demonstrated that $\mathrm{T}$ stage and lymph node metastasis were significantly associated with strong FGFR-1 expression in lung cancer. Devilard et al (37) also reported that $\mathrm{T}$ stage correlated with FGFR-1 expression in prostate cancer. In our study, FGFR-1 expression was associated with liver metastasis, but the expression levels of the $F G F-1$, $F G F-2$, and $F G F R-2$ genes were not significantly related to any clinicopathological feature examined.

In conclusion, our results suggest that overexpression of the FGFR-1 gene correlates with liver metastasis in colorectal cancer. High levels of FGFR-1 gene expression may thus be a novel marker or predictor of liver metastasis.

\section{References}

1. Presta M, Dell'Era P, Mitola S, Moroni E, Ronca R and Rusnati M: Fibroblast growth factor/fibroblast growth factor receptor system in angiogenesis. Cytokine Growth Factor Rev 16: 159-178, 2005.

2. Gospodarowicz D: Localisation of a fibroblast growth factor and its effect alone and with hydrocortisone on $3 \mathrm{t} 3$ cell growth. Nature 249: 123-127, 1974.

3. Ribatti D, Vacca A, Rusnati M and Presta M: The discovery of basic fibroblast growth factor/fibroblast growth factor- 2 and its role in haematological malignancies. Cytokine Growth Factor Rev 18: 327-334, 2007.

4. Galzie Z, Kinsella AR and Smith JA: Fibroblast growth factors and their receptors. Biochem Cell Biol 75: 669-685, 1997.

5. Yoshimura N, Sano H, Hashiramoto A, Yamada R, Nakajima H, Kondo $\mathrm{M}$ and Oka T: The expression and localization of fibroblast growth factor-1 (fgf-1) and fgf receptor-1 (fgfr-1) in human breast cancer. Clin Immunol Immunopathol 89: 28-34, 1998.

6. Yiangou C, Gomm JJ, Coope RC, Law M, Luqmani YA, Shousha S, Coombes RC and Johnston CL: Fibroblast growth factor 2 in breast cancer: Occurrence and prognostic significance. Br J Cancer 75: 28-33, 1997.

7. Bansal GS, Yiangou C, Coope RC, Gomm JJ, Luqmani YA, Coombes RC and Johnston CL: Expression of fibroblast growth factor 1 is lower in breast cancer than in the normal human breast. Br J Cancer 72: 1420-1426, 1995.

8. Luqmani YA, Graham M and Coombes RC: Expression of basic fibroblast growth factor, fgfr1 and fgfr2 in normal and malignant human breast, and comparison with other normal tissues. Br J Cancer 66: 273-280, 1992.

9. Akutsu Y, Aida T, Nakazawa S and Asano G: Localization of acidic and basic fibroblast growth factor mrna in human brain tumors. Jpn J Cancer Res 82: 1022-1027, 1991.

10. Morrison RS, Yamaguchi F, Bruner JM, Tang M, McKeehan W and Berger MS: Fibroblast growth factor receptor gene expression and immunoreactivity are elevated in human glioblastoma multiforme. Cancer Res 54: 2794-2799, 1994.

11. Yamaguchi F, Saya H, Bruner JM and Morrison RS: Differential expression of two fibroblast growth factor-receptor genes is associated with malignant progression in human astrocytomas. Proc Natl Acad Sci USA 91: 484-488, 1994.

12. Auguste P, Gursel DB, Lemiere S, Reimers D, Cuevas P, Carceller F, Di Santo JP and Bikfalvi A: Inhibition of fibroblast growth factor/fibroblast growth factor receptor activity in glioma cells impedes tumor growth by both angiogenesis-dependent and -independent mechanisms. Cancer Res 61: 1717-1726, 2001.

13. Kin M, Sata M, Ueno T, Torimura T, Inuzuka S, Tsuji R, Sujaku K, Sakamoto M, Sugawara H, Tamaki S and Tanikawa K: Basic fibroblast growth factor regulates proliferation and motility of human hepatoma cells by an autocrine mechanism. J Hepatol 27: 677-687, 1997.

14. Chow NH, Cheng KS, Lin PW, Chan SH, Su WC, Sun YN and Lin XZ: Expression of fibroblast growth factor-1 and fibroblast growth factor-2 in normal liver and hepatocellular carcinoma. Dig Dis Sci 43: 2261-2266, 1998. 
15. Huang X, Yu C, Jin C, Kobayashi M, Bowles CA, Wang F and McKeehan WL: Ectopic activity of fibroblast growth factor receptor 1 in hepatocytes accelerates hepatocarcinogenesis by driving proliferation and vascular endothelial growth factorinduced angiogenesis. Cancer Res 66: 1481-1490, 2006.

16. Hase T, Kawashiri S, Tanaka A, Nozaki S, Noguchi N, Kato K, Nakaya $\mathrm{H}$ and Nakagawa K: Correlation of basic fibroblast growth factor expression with the invasion and the prognosis of oral squamous cell carcinoma. J Oral Pathol Med 35: 136-139, 2006.

17. Sugiura K, Ozawa S, Kitagawa Y, Ueda M and Kitajima M: Co-expression of afgf and fgfr-1 is predictive of a poor prognosis in patients with esophageal squamous cell carcinoma. Oncol Rep 17: 557-564, 2007.

18. Hase T, Kawashiri S, Tanaka A, Nozaki S, Noguchi N, Kato K, Nakaya H, Nakagawa K and Yamamoto E: Fibroblast growth factor-2 accelerates invasion of oral squamous cell carcinoma. Oral Sci Int 3: 1-9, 2006.

19. Freier K, Schwaenen C, Sticht C, Flechtenmacher C, Muhling J, Hofele C, Radlwimmer B, Lichter P and Joos S: Recurrent fgfr1 amplification and high fgfr1 protein expression in oral squamous cell carcinoma (oscc). Oral Oncol 43: 60-66, 2007.

20. Myoken Y, Okamoto T, Kan M, McKeehan WL, Sato JD and Takada K: Expression of fibroblast growth factor-1 (fgf-1), fgf-2 and fgf receptor-1 in a human salivary-gland adenocarcinoma cell line: Evidence of growth. Int J Cancer 65: 650-657, 1996.

21. Yamanaka Y, Friess H, Buchler M, Beger HG, Uchida E, Onda M, Kobrin MS and Korc M: Overexpression of acidic and basic fibroblast growth factors in human pancreatic cancer correlates with advanced tumor stage. Cancer Res 53: 5289-5296, 1993.

22. Kobrin MS, Yamanaka Y, Friess H, Lopez ME and Korc M: Aberrant expression of type i fibroblast growth factor receptor in human pancreatic adenocarcinomas. Cancer Res 53: 4741-4744, 1993

23. Liu Z, Neiss N, Zhou S, Henne-Bruns D, Korc M, Bachem M and Kornmann M: Identification of a fibroblast growth factor receptor 1 splice variant that inhibits pancreatic cancer cell growth. Cancer Res 67: 2712-2719, 2007.

24. Acevedo VD, Gangula RD, Freeman KW, Li R, Zhang Y, Wang F, Ayala GE, Peterson LE, Ittmann M and Spencer DM: Inducible fgfr-1 activation leads to irreversible prostate adenocarcinoma and an epithelial-to-mesenchymal transition. Cancer Cell 12: 559-571, 2007

25. Freeman KW, Gangula RD, Welm BE, Ozen M, Foster BA, Rosen JM, Ittmann M, Greenberg NM and Spencer DM: Conditional activation of fibroblast growth factor receptor (fgfr) 1 , but not fgfr2, in prostate cancer cells leads to increased osteopontin induction, extracellular signal-regulated kinase activation, and in vivo proliferation. Cancer Res 63: 6237-6243, 2003.
26. Feng S, Wang F, Matsubara A, Kan M and McKeehan WL: Fibroblast growth factor receptor 2 limits and receptor 1 accelerates tumorigenicity of prostate epithelial cells. Cancer Res 57: 5369-5378, 1997.

27. Jang JH: Reciprocal relationship in gene expression between fgfr1 and fgfr3: Implication for tumorigenesis. Oncogene 24: 945-948, 2005

28. Galzie Z, Fernig DG, Smith JA, Poston GJ and Kinsella AR: Invasion of human colorectal carcinoma cells is promoted by endogenous basic fibroblast growth factor. Int J Cancer 71: 390-395, 1997.

29. Galzie Z, Fernig DG, Smith JA, Poston GJ and Kinsella AR: Basic fibroblast growth factor and colorectal carcinoma invasion. Biochem Soc Trans 24: S501, 1996.

30. Katoh M: Fgf signaling network in the gastrointestinal tract (Review). Int J Oncol 29: 163-168, 2006.

31. Myoken Y, Okamoto T, Sato JD and Takada K: Immunocytochemical localization of fibroblast growth factor-1 (fgf-1) and fgf-2 in oral squamous cell carcinoma (scc). J Oral Pathol Med 23: 451-456, 1994

32. Sahadevan K, Darby S, Leung HY, Mathers ME, Robson CN and Gnanapragasam VJ: Selective over-expression of fibroblast growth factor receptors 1 and 4 in clinical prostate cancer. J Pathol 213: 82-90, 2007

33. Takanami I, Tanaka F, Hashizume T, Kikuchi K, Yamamoto Y, Yamamoto T and Kodaira S: The basic fibroblast growth factor and its receptor in pulmonary adenocarcinomas: An investigation of their expression as prognostic markers. Eur J Cancer 32A: 1504-1509, 1996.

34. Suyama K, Shapiro I, Guttman M and Hazan RB: A signaling pathway leading to metastasis is controlled by n-cadherin and the fgf receptor. Cancer Cell 2: 301-314, 2002.

35. Han B, Liu J, Ma MJ and Zhao L: Clinicopathological significance of heparanase and basic fibroblast growth factor expression in human esophageal cancer. World J Gastroenterol 11: 2188-2192, 2005

36. Mano Y, Takahashi K, Ishikawa N, Takano A, Yasui W, Inai K, Nishimura H, Tsuchiya E, Nakamura Y and Daigo Y: Fibroblast growth factor receptor 1 oncogene partner as a novel prognostic biomarker and therapeutic target for lung cancer. Cancer Sci 98: 1902-1913, 2007.

37. Devilard E, Bladou F, Ramuz O, Karsenty G, Dales JP, Gravis G, Nguyen C, Bertucci F, Xerri L and Birnbaum D: Fgfr1 and wt1 are markers of human prostate cancer progression. BMC Cancer 6: $272,2006$. 